\title{
BRAND EXPERIENCE CLUSTERING AND DEPICTION OF BRAND SATISFACTION, BRAND LOYALTY AND EMOTIONAL CONFIDENCE
}

\author{
Wajid H RIZVI*, Salman MEMON**, Abdul Samad DAHRI*** \\ *Institute of Business Administration, Karachi, Sindh, PAKISTAN \\ e-mail: wrizvi@iba.edu.pk \\ **Shah Abdul Latif University, Khairpur, Sindh, PAKISTAN \\ e-mail: salman.memon@salu.edu.pk \\ ***Muhammad Ali Jinnah University, Karachi, Sindh, PAKISTAN \\ e-mail: dahriabdulsamad@gmail.com
}

\begin{abstract}
Brand experience (BE) is essential to depict long-term consumer brand relationships; this study investigates the influence of brand experience on emotional confidence (EC) and subsequent impact of brand satisfaction (BS) and brand loyalty (BL) in the context of car buying. Structural equation modeling was used to affirm the hypothesized relationships. This study further explores dimensions of brand experience: sensory, affective, intellectual and behavioral concerning EC, BS, and BL. Hierarchical cluster analysis was performed to depict the relationship as a consequence, and four clusters were identified. The results of the structural model suggest that there is a positive and statistically significant influence of $\mathrm{BE}$ on $\mathrm{EC}$, there is a positive and statistically significant influence of $\mathrm{EC}$ on $\mathrm{BS}$, and there is a positive and statistically significant influence of $\mathrm{BS}$ on $\mathrm{BL}$. When the direct path from $\mathrm{EC}$ to $\mathrm{BL}$ was added to the model, it increased the variance explained in $\mathrm{BL}$ and coefficient of $\mathrm{EC}$ was higher than the coefficient of BS suggesting that $\mathrm{EC}$ is an important construct within the formwork. The results of hierarchical cluster analysis identified four clusters; the relationship among EC, BS and BL showed interesting patterns; there were higher correspondents between EC and BL than between BS and BL; the pattern was consistent with the results of the structural model. The data was collected from car showrooms across Karachi city; the respondents were users of the brand.
\end{abstract}

Keywords: brand experience, brand satisfaction, brand loyalty and emotional confidence.

JEL Classification: M31.

\section{Introduction}

Widespread brand choice and consumers empowered by digital gadgets have posed a considerable challenge for marketing practitioners to sustain the longterm brand-consumer relationship (Das, et al., 2018). To understand the long-term brand-consumer relationship, different evaluative (i.e., brand attitude) and motivational (i.e., brand attachment) marketing constructs have been tested (Ajzen, 2005; Park, et al., 2010). These constructs have certainly enriched our understanding of the relationship. However, emotional confidence, despite its recognition and importance, has received little or no attention in the academic literature (Kidwell, et al., 2008; Rizvi and Oney, 2018). The emotional confidence (EC) is defined as affective certainty based strong emotional response, which is essential for a long-term brandconsumer relationship (Rizvi and Oney, 2018).
The EC as a construct has just surfaced in the literature and its antecedents and consequents are not well documented. Therefore, this study explores its relationship within the existing marketing frameworks. Rizvi and Oney (2018) argue that emotional confidence is a consequence of overall brand experience; presumably, stronger the brand experience, stronger is the affective certainty towards a brand.

Brand experience is considered a core interaction that may lead to various consequences such as brand satisfaction and brand loyalty (Brakus, et al., 2009). Brand experience as a construct is well documented in the academic literature, and it is further explored for possible consumer profiling, namely there are four dimensions of brand experience: sensory, affective, intellectual and behavioral (Zarantonello and Schmitt, 2010) and how it influences other constructs like brand commitment (Das, et al., 2018). 
This study investigates the influence of brand experience on emotional confidence and whether or not emotional confidence influences brand satisfaction and brand loyalty. Further, clusters of brand experience dimensions were elicited to analyze the relevance of the elicited clusters concerning emotional confidence, brand satisfaction and brand loyalty.

To the best of our knowledge, no study has investigated the influence of brand experience on emotional confidence. It is important to note that consumer profiling based on the brand experience dimensions exists and its relative impact on purchase intentions is affirmed. However, such consumer profiles are not analyzed regarding emotional confidence, brand satisfaction, and brand loyalty. This paper mainly deals with two major questions:

1) Does brand experience influence emotional confidence, and its relationship with brand satisfaction and brand loyalty is investigated?

2) Does consumer profiling based on consumer brand experience enrich our understanding of the relationship between emotional confidence, brand satisfaction, and brand loyalty?

\subsection{Background}

Brand experience has captured the attention of both academics and practitioners. Brand experience is a multi-dimensional construct consisting of sensory, affective, intellectual and behavioral dimensions (Brakus, et al., 2009). Although brand experience can be positive or negative, its measure implies positive experience towards a brand. It is neither an evaluative construct like brand attitude, nor a motivational construct like brand attachment. The dimensions of the brand experience are also used to profile consumer and to investigate its influence on purchase intentions (Zarantonello and Schmitt, 2010). The brand experience is used to assess its impact on brand satisfaction, brand loyalty and brand commitment (Das, et al., 2018; Brakus, et al., 2009).

Confidence as a construct is widely used in behavioral science. It is considered a key and one of the most critical indicators of economic health. Despite its widespread use, the conceptual domain of confidence remains uncharted. The conceptual ambiguity poses a challenge regarding how to measure it, mostly confidence as a construct is conceptualized as a cognitive construct; despite highlighting urge and importance of emotional confidence (Kidwell, et al., 2008), very little progress has been made (Rizvi and Oney, 2018). Emotional confidence is conceptualized as an affective certainty based on strong emotions. However, emotional confidence is neither an evaluative construct like brand attitude, nor a motivational construct like brand attachment; conceptually, it is similar to brand experience. However, emotional confidence is a consequence of brand experience. Positive or negative brand experience may result in affective certainty (i.e., emotional confidence) to act. Both strong positive and negative brand experience can trigger affective certainty to act or not to act. But it is important to note in this study: emotional confidence is measured based on "strong positive emotions". From a measurement perspective, brand experience implies positive experience, even though brand experience can be positive or negative.

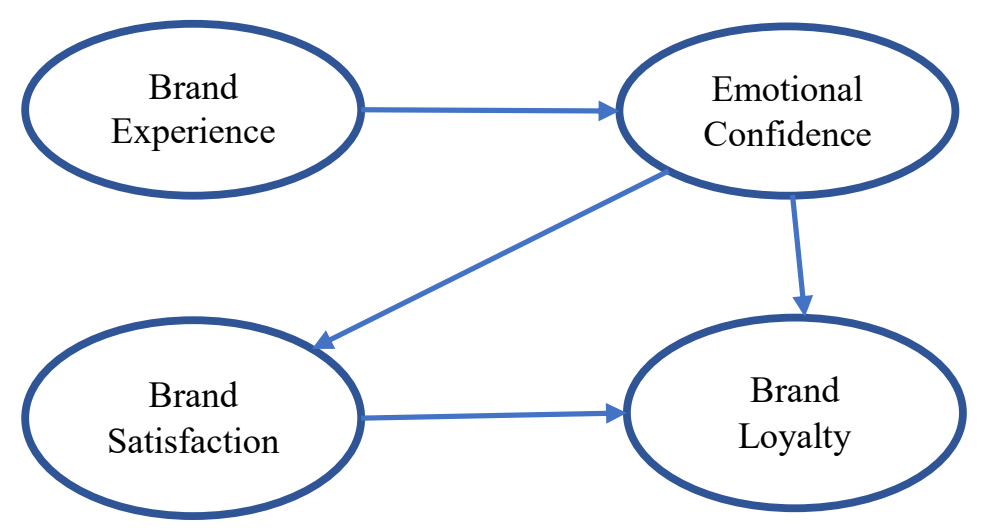

Figure 1. The Conceptual Framework (Source: Own research) 
Stemming from recent development, Rizvi and Oney (2018) argue that emotional confidence can be a consequence of overall brand experience. Since antecedents of emotional confidence are not yet specified in the literature, it will be interesting to see whether or not brand experience influence emotional confidence. Moreover, Brakus, et al. (2009) have shown that brand experience could affect brand satisfaction and brand loyalty. In this study, we employ the same framework only by adding emotional confidence as a consequence of brand experience and as an antecedent of brand satisfaction and brand loyalty. Further, consumers are clustered based on brand experience dimensions to depict the relationship among emotional confidence, brand satisfaction, and brand loyalty. Based on the theoretical model as well as the theoretical background presented above, the following hypothesis has been developed for the research study (the conceptual framework can be seen in Fig. 1):

$\mathrm{H}_{1}$ : Brand experience has a direct and a positive influence on emotional confidence.

$\mathrm{H}_{2}$ : Emotional confidence has a direct and positive influence on consumer brand satisfaction.

$\mathrm{H}_{3}$ : Consumer brand satisfaction as a direct and positive influence on consumer brand loyalty.

$\mathrm{H}_{4}$ : Emotional confidence has a direct positive influence on brand loyalty.

\section{$2 \quad$ Methodology}

The focus of this study was two-pronged, first to assess the influence of brand experience on emotional confidence, second clustering of brand experience dimensions to depict the relationship between emotional confidence, brand satisfaction and brand loyalty. A self-administered questionnaire was used to collect data $(n=240)$ in the context of car buying. Judgment sampling was used to obtain the data as prior experience (users of the brand) was warranted; so data was collected from various car service centers and the participation in the study was voluntary.

For this, validated scales of all constructs were used and the measures included brand experience, brand satisfaction, emotional confidence and brand loyalty (Brakus, et al., 2009; Oliver, 1999; Rizvi and Oney, 2018).

Structural equation modeling (AMOS) was used to analyze the data for the first part of the paper. For the second part of the paper, the four dimensions of the brand experience: sensory, affective, behavioral and intellectual were clustered to further assess the relationship among emotional confidence, brand satisfaction and brand loyalty within those clusters. Hierarchical cluster analysis was used (SPSS), as there were no prior assumptions regarding the number of clusters; the clusters were extracted by employing Ward's method to get a sizable cluster for further analysis. To validate the solution, both subsample and discriminant analysis were performed.

\section{Data Analysis}

Table 1 contains a descriptive analysis of demographic profile obtained from 251 respondents based on four demographic aspects, namely age, marital status, family income and driving Toyota experience.

Table 1. Demographic Profile (Source: Own research)

\begin{tabular}{|c|c|c|c|c|c|c|c|}
\hline Age & Percent & $\begin{array}{c}\text { Marital } \\
\text { Status }\end{array}$ & Percent & $\begin{array}{c}\text { Family } \\
\text { Income (PKR) }\end{array}$ & Percent & $\begin{array}{c}\text { Driving } \\
\text { Toyota } \\
\text { Experience }\end{array}$ & Percent \\
\hline Under 16 & $2(0.8)$ & Married & $(156) 62.4$ & Under 25,000 & $18(7.2)$ & 0 & $16(6.4)$ \\
\hline $17-25$ & $66(26.4)$ & Single & $(94) 37.6$ & $25,001-50,000$ & $22(8.8)$ & $1-3$ & $120(48.0)$ \\
\hline $26-35$ & $54(21.6)$ & & & $50,001-75,000$ & $37(14.8)$ & $4-5$ & $74(29.6)$ \\
\hline $36-50$ & $85(34.0)$ & & & $75,001-125,000$ & $95(38.0)$ & $6+$ & $40(16.0)$ \\
\hline $51-60$ & $36(14.4)$ & & & $125,001-200,000$ & $78(31.2)$ & & \\
\hline Over 60 & $7(2.8)$ & & & & & & \\
\hline Frequency & \multicolumn{7}{|l}{251} \\
\hline
\end{tabular}


Accordingly, the prime number of respondents, that is, $85(34 \%)$ respondents from the age group 36-50 years, while 66 (26.4\%) respondents from age group 17-25 years. Likewise, 54 (21.6\%) respondents from age group 26-35 years. Also, the results indicate that $156(62.4 \%)$ respondents were married and 94 $(37.6 \%)$ respondents were single. Regarding family income, $95(38 \%)$ respondents were from the family income group 75,001-125,000 PKR. Also, 78 (31.2\%) respondents were from the family income group 125,001-200,000. About driving Toyota experience, the demographic profile results indicate that
120 (48\%) respondents were 1-3 years' experience of driving Toyota as compared to $74(29.6 \%)$ respondents with 4-5 years' experience.

\subsection{Internal Consistency Reliability Test}

An instrument used to conduct the self-administrative survey was based on two independents (i.e., emotional confidence $\&$ brand satisfaction) and two dependents (i.e., brand experience \& brand loyalty) variable(s).

Table 2. Reliability, Mean, Std. Deviation \& Factor Extracted with PCA (Source: Own research)

\begin{tabular}{|c|c|c|c|c|}
\hline Scale & Item & Mean & Std. Dev & Extraction \\
\hline \multirow{7}{*}{ 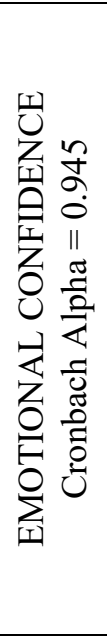 } & $\begin{array}{l}\text { BEC1: Strong positive feelings play an essential role while buying } \\
\text { Toyota Car }\end{array}$ & 5.15 & 1.593 & 0.815 \\
\hline & $\begin{array}{l}\text { BEC2: My strong positive feelings towards Toyota car } \\
\text { gives me certainty to buy it }\end{array}$ & 5.28 & 1.497 & 0.838 \\
\hline & $\begin{array}{l}\text { BEC3: My Strong positive feelings guide my purchase } \\
\text { of Toyota car }\end{array}$ & 5.20 & 1.402 & 0.817 \\
\hline & $\begin{array}{l}\text { BEC4: I rely on my strong positive feelings while buying } \\
\text { the Toyota car }\end{array}$ & 5.19 & 1.459 & 0.808 \\
\hline & $\begin{array}{l}\text { BEC5: When I have strong positive feelings about } \\
\text { the Toyota then it is easier to decide }\end{array}$ & 5.23 & 1.335 & 0.772 \\
\hline & $\begin{array}{l}\text { BEC6: My overall strong positive feelings towards } \\
\text { Toyota makes me certain to buy it }\end{array}$ & 5.24 & 1.447 & 0.761 \\
\hline & $\begin{array}{l}\text { BEC7: My strong positive feelings about Toyota increase } \\
\text { the likelihood of buying it again in future }\end{array}$ & 5.08 & 1.468 & 0.649 \\
\hline \multirow{4}{*}{ 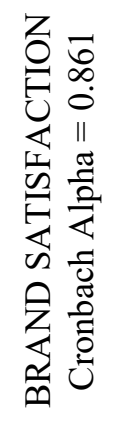 } & BPQ1: Toyota offers very good quality cars & 5.45 & 1.192 & 0.712 \\
\hline & BPQ2: Toyota offers cars of consistent quality & 5.25 & 1.246 & 0.706 \\
\hline & BPQ3: Toyota offers very reliable cars & 5.30 & 1.264 & 0.739 \\
\hline & BPQ4: Toyota offers cars with excellent features & 5.28 & 1.278 & 0.718 \\
\hline \multirow{6}{*}{ 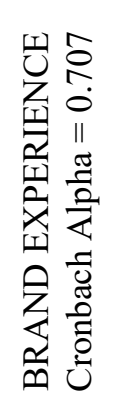 } & BEX1: Sensory & 5.07 & 1.339 & 0.717 \\
\hline & BEX2: Sensory & 4.86 & 1.413 & 0.683 \\
\hline & BEX3: Behavioural & 3.87 & 1.641 & 0.859 \\
\hline & BEX4: Behavioural & 3.82 & 1.759 & 0.896 \\
\hline & BEX5: Intellectual & 4.24 & 1.849 & 0.539 \\
\hline & BEX6: Intellectual & 4.58 & 1.543 & 0.671 \\
\hline
\end{tabular}


Table 2. Reliability, Mean, Std. Deviation \& Factor Extracted with PCA (cont.) (Source: Own research)

\begin{tabular}{|c|c|c|c|c|}
\hline Scale & Item & Mean & Std. Dev & Extraction \\
\hline \multirow{5}{*}{ 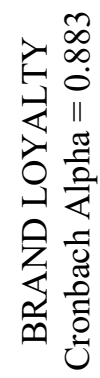 } & BL1: In the future, I will be loyal to Toyota brand & 4.84 & 1.399 & 0.713 \\
\hline & BL2: I will buy Toyota again & 5.02 & 1.385 & 0.715 \\
\hline & BL3: Toyota will be my first choice in the future & 4.74 & 1.523 & 0.782 \\
\hline & BL4: I will not buy other car brands & 4.13 & 1.780 & 0.630 \\
\hline & BL5: I will recommend Toyota to others & 4.89 & 1.387 & 0.651 \\
\hline
\end{tabular}

For measuring emotional confidence, a total of 07 item(s) scale was used. Whereas, brand satisfaction, brand loyalty and brand experience were measured with $05,04,04$ item(s) scale, respectively. Internal consistency of measurement is pivotal for the quality of results (Weijters, Cabooter and Schillewaert, 2010). Hence, a five-point Likert scale anchored between $1=$ strongly disagree to $5=$ strongly agree was used to encourage unbiased responses (Greenleaf, 1992). Refer to the results summarized in Table 2, the internal consistency reliability values of four scales (i.e., $\mathrm{BEC}=0.945 ; \mathrm{BPQ}=0.861 ; \mathrm{BEX}=0.707$ and $\mathrm{BL}=0.883$ ) found to be acceptable between advised limits, that is, $0.70-0.90$.

\subsection{KMO and Bartlett's Test}

Refer to the results summarized in Table 3, KMO (i.e., Kaiser-Meyer-Olkin) shows the fitness of the data for the strength of a factor structure. For instance, KMO value (i.e., .917 close to 1) indicates that correlations are reasonably well so that the strength of a factor structure could be attained (Hutcheson and Sofroniou, 1999). However, the "Bartlett's Sphericity" reveals the dissimilarity between variables, which is a signpost of aptness or inaptness of a factor structure detection. For example, the smaller $\chi^{2}$ value, that is, 3959.76 significant at $\mathrm{p}<0.05$ show that a "factor analysis" could be suitable with the data.

Table 3. KMO and Bartlett's Test (Source: Own research)

\begin{tabular}{|l|l|c|}
\hline \multicolumn{2}{|l|}{ Kaiser-Meyer-Olkin Measure of Sampling Adequacy } & 0.917 \\
\hline \multirow{3}{*}{ Bartlett's Test of Sphericity } & Approx. Chi-Square & 3959.761 \\
\cline { 2 - 3 } & Df & 231 \\
\cline { 2 - 3 } & Sig. & 0.000 \\
\hline
\end{tabular}

\subsection{Confirmatory Factor Analysis}

For factor extraction, a principal component analysis method was used to establish an independent linear combination of observed variables. Extraction values provided in Table 2 show the amount of variance that is explained by each factor. The variables with a high amount of variance indicate the strength of variable regarding their highest representation, whereas, variables with the lowest amount of variance indicates the low representation in the factor space. For example, BEX4 $=0.896$ and BEX3 $=0.859$ indicates the high proportion of variance. In contrast, BL4 $=0.630$ and BEC7 $=0.649$ indicates the low proportion of variance in the factor space. Scree plot also indicates the percentage of "variance" in a factor structure (space). A scree plot exhibited in Fig. 2 shows the maximum variation in 6 factors as the eigenvalues on the y-axis flatten at $6^{\text {th }}$ factor and remaining factors explain a minimal variation. 


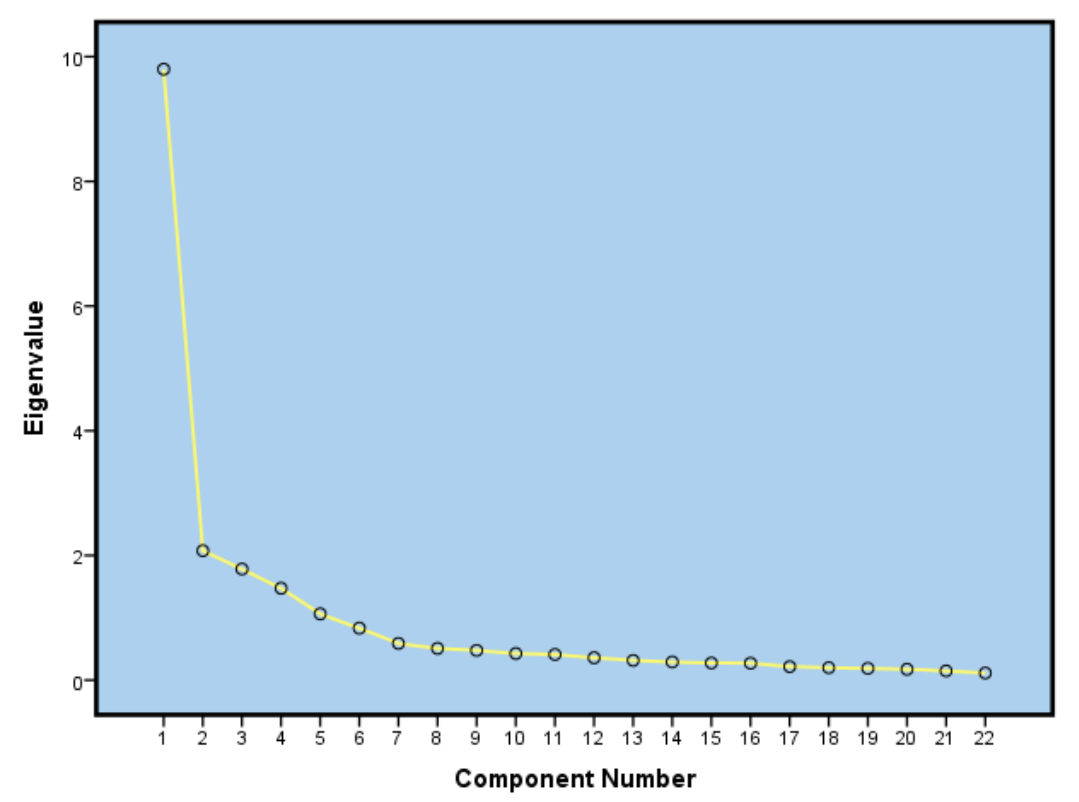

Figure 2. Scree Plot (Source: Own research)

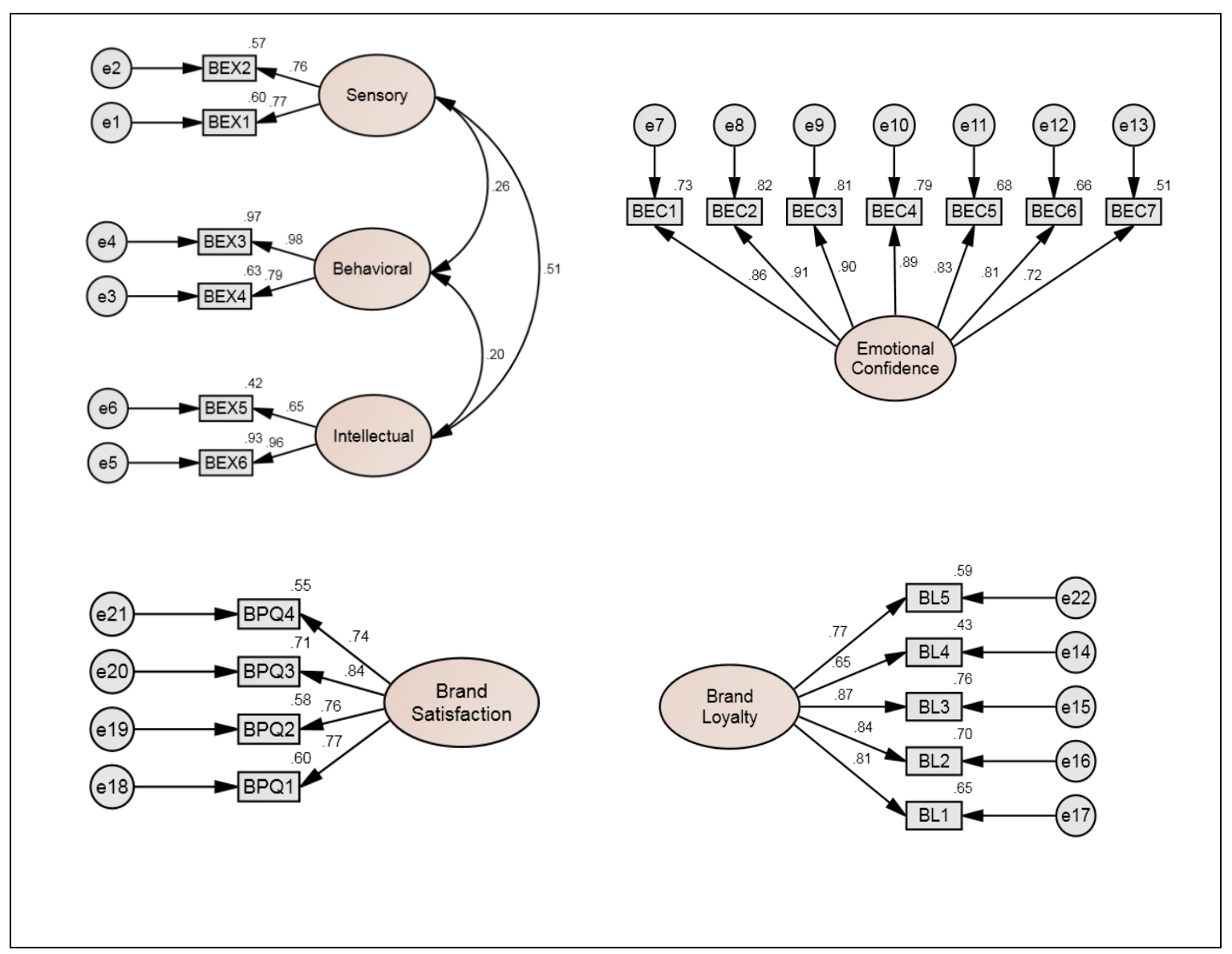

Figure 3. CFA Model (Source: Own research) 


\subsection{Confirmatory Factor Analysis}

KMO value greater than 0.7 is an indication for "confirmatory factor analysis" (Hair, et al., 2010). Therefore, IBM-AMOS v19 was used to test the "confirmatory factor analysis" (see Fig. 3) independently before the "structural equation model" (Anderson and Gerbing, 1988). In order to use the "maximum likelihood" estimation method, data normality was confirmed as the values of Kurtosis $(-0.548 \& 0.825)$ and Skewness (-1.485 \& -0.838$)$ shown to be normally distributed and consistent with the suggested limits (Kline, 2015). Refer to Table 4, all factor loadings ( $\lambda$ values) of 04 variables and 22 items are measured above-suggested limit 0.50 statistically significant at $\mathrm{p}<0.000$.

The composite reliability (CR) values $(0.886$ and 0.960 ) and average variance extraction (AVE) values ( 0.568 and 0.82$)$ also measured between the suggested limits thus satisfied the "structural reliability" and "convergent validity" of the construct(s) used in this study (Bagozzi and Yi, 2012; Fornell and Larcker, 1981).

Table 4. CFA based Reliability \& Validity (Source: Own research)

\begin{tabular}{|c|c|c|c|c|c|c|}
\hline Variables & Factor Loading & t-value & $\mathrm{R}^{2}$ & $\alpha$ (alpha) & $\mathrm{CR}$ & AVE \\
\hline \multicolumn{7}{|c|}{ Emotional Confidence } \\
\hline BEC1 & 0.855 & Fixed $^{\circ}$ & 0.731 & \multirow{7}{*}{0.920} & \multirow{7}{*}{0.944} & \multirow{7}{*}{0.875} \\
\hline $\mathrm{BEC} 2$ & 0.906 & 19.856 & 0.820 & & & \\
\hline BEC3 & 0.898 & 19.536 & 0.806 & & & \\
\hline BEC4 & 0.888 & 19.099 & 0.788 & & & \\
\hline BEC5 & 0.827 & 16.788 & 0.684 & & & \\
\hline BEC6 & 0.813 & 16.319 & 0.662 & & & \\
\hline BEC7 & 0.718 & 13.400 & 0.515 & & & \\
\hline \multicolumn{7}{|l|}{ Brand Satisfaction } \\
\hline BPQ1 & 0.772 & Fixed $^{\circ}$ & 0.596 & \multirow{4}{*}{0.925} & \multirow{4}{*}{0.963} & \multirow{4}{*}{0.682} \\
\hline BPQ2 & 0.761 & 11.818 & 0.580 & & & \\
\hline BPQ3 & 0.844 & 12.933 & 0.713 & & & \\
\hline BPQ4 & 0.742 & 11.504 & 0.551 & & & \\
\hline \multicolumn{7}{|l|}{ Brand Experience } \\
\hline BEX1 & 0.775 & Fixed $^{\circ}$ & 0.600 & \multirow{6}{*}{0.882} & \multirow{6}{*}{0.815} & \multirow{6}{*}{0.572} \\
\hline BEX2 & 0.755 & 6.821 & 0.570 & & & \\
\hline BEX3 & 0.985 & 4.999 & 0.970 & & & \\
\hline BEX4 & 0.794 & Fixed $^{\circ}$ & 0.631 & & & \\
\hline BEX5 & 0.645 & 5.806 & 0.471 & & & \\
\hline BEX6 & 0.964 & Fixed $^{\circ}$ & 0.928 & & & \\
\hline \multicolumn{7}{|l|}{ Brand Loyalty } \\
\hline BL1 & 0.805 & 10.754 & 0.649 & \multirow{5}{*}{0.838} & \multirow{5}{*}{0.802} & \multirow{5}{*}{0.851} \\
\hline BL2 & 0.837 & 11.072 & 0.701 & & & \\
\hline BL3 & 0.873 & 11.395 & 0.763 & & & \\
\hline BL4 & 0.652 & Fixed $^{\circ}$ & 0.425 & & & \\
\hline BL5 & 0.766 & 10.337 & 0.586 & & & \\
\hline
\end{tabular}


Refer to the results summarized in Table 5, the $\chi^{2}$ value attained significance at $p<0.000$. In case of all four variables (i.e., emotional confidence, brand experience, brand satisfaction and brand loyalty), model fit indicators (e.g., AGFI, RMR, CFI, TLI, NFI and RMSEA) are methodically compatible with the sample data.

Table 5. Confirmatory Factor Analysis (Source: Own research)

\begin{tabular}{|c|c|c|c|c|c|c|c|c|c|}
\hline \multicolumn{10}{|c|}{ Fit Indices } \\
\hline & $\chi^{2}$ & $\mathrm{df}$ & $\chi^{2 / \mathrm{df}}$ & AGFI & RMR & CFI & TLI & NFI & RMSEA \\
\hline Emotional Confidence & 87.324 & 34 & 2.56 & 0.798 & 0.075 & 0.954 & 0.931 & 0.946 & 0.145 \\
\hline Brand Experience & 16.034 & 06 & 2.67 & 0.925 & 0.080 & 0.981 & 0.952 & 0.970 & 0.082 \\
\hline Brand Satisfaction & 2.568 & 02 & 1.28 & 0.975 & 0.020 & 0.999 & 0.996 & 0.994 & 0.034 \\
\hline Brand Loyalty & 19.016 & 05 & 3.80 & 0.915 & 0.049 & 0.980 & 0.960 & 0.973 & 0.106 \\
\hline
\end{tabular}

\subsection{Structural Equation Model}

Fig. 4 shows the path diagram of a Structural Model 1. The model fit results appear in Table 6. The $\chi^{2}$ achieved significance at $p<0.000$. Likewise, the level of discrepancy was measured with $\chi^{2}$ / df. The measured value (i.e., $600.738 / 203=2.95$ between 2 or 3 ) also shows the model fit. Besides, other 06 model fit indices such as, $\mathrm{AGFI}=0.780 ; \mathrm{RMR}=0.250 ; \mathrm{CFI}=$ $0.897 ; \mathrm{TLI}=0.883 ; \mathrm{NFI}=0.853$ and $\mathrm{RMSEA}=0.089$ indicates an "adequate model fit" as per the suggested brackets.

Hypothesis testing results based on Model 1 are listed in Table 7.

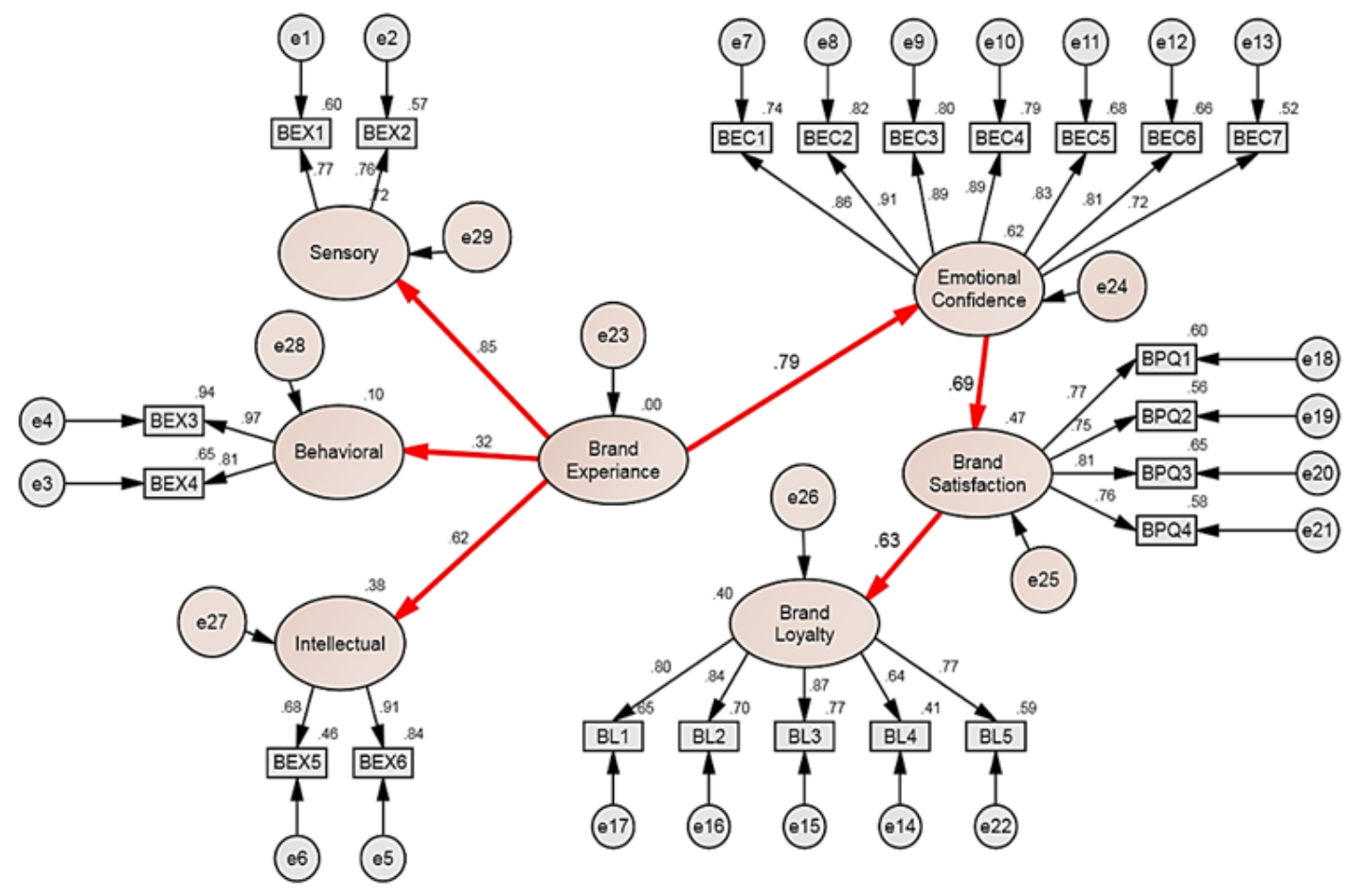

Figure 4. Structural Model 1 (Source: Own research) 
Table 8. Fit Indices based on Model 2 (Source: Own research)

\begin{tabular}{|c|c|c|c|c|c|c|c|c|}
\hline$x^{2}$ & df & $\chi^{2 / \mathrm{df}}$ & AGFI & RMR & CFI & TLI & NFI & RMSEA \\
\hline 560.370 & 202 & 2.77 & 0.786 & 0.186 & 0.907 & 0.894 & 0.863 & 0.084 \\
\hline \multicolumn{9}{|c|}{$\begin{array}{l}\text { Probability level }=0.000 \\
\chi 2 \text { - chi-square; AGFI - adjusted goodness-of-fit; RMR - root-mean-square; CFI - comparative fit index; } \\
\text { TLI - Trucker-Lewis Coefficient; NFI - normed fit index; and RMSEA - root-mean-square error of approximation }\end{array}$} \\
\hline
\end{tabular}

Table 9. Hypothesis Testing Results based on Model 2 (Source: Own research)

\begin{tabular}{|c|c|c|c|c|c|}
\hline $\mathrm{R}$ & Estimate & $\mathrm{R}^{2}$ & S.E & ot-value & ${ }^{\circ o} \mathrm{p}$-value \\
\hline \multicolumn{6}{|c|}{ H1: Brand experience has a direct and a positive influence on emotional confidence } \\
\hline 0.797 & 1.260 & 0.635 & 0.181 & 6.955 & $* * *$ \\
\hline \multicolumn{6}{|c|}{ H2: Emotional confidence has a direct and positive influence on consumer brand satisfaction } \\
\hline 0.647 & 0.439 & 0.418 & 0.047 & 9.340 & $* * *$ \\
\hline \multicolumn{6}{|c|}{ H3: Emotional confidence has a direct and positive influence on consumer brand loyalty } \\
\hline 0.496 & 0.412 & 0.246 & 0.070 & 5.857 & $* * *$ \\
\hline \multicolumn{6}{|c|}{ H4: Consumer brand satisfaction as a direct and positive influence on consumer brand loyalty } \\
\hline 0.258 & 0.315 & 0.066 & 0.098 & 3.216 & 0.001 \\
\hline \multicolumn{6}{|c|}{$\begin{array}{l}\text { ot value }=0.439 / 0.047=9.340 \\
{ }^{\circ} \text { The probability of attaining a t-value (critical ratio) as high as } 9.359 \text { in absolute value is } \leq 0.001 \text {. More specifically, } \\
\text { the regression weight for Emotional Confidence in the prediction of Consumer Brand Satisfaction is significantly dif- } \\
\text { ferent from zero at the } 0.001 \text { level (two-tailed). }\end{array}$} \\
\hline
\end{tabular}

\section{$4 \quad$ Hypothesis Testing Results}

Fig. 6 shows the path estimates based on both Model 1 and Model 2.

The first research hypothesis assumes that "brand experience (BEX) has a direct and a positive influence on emotional confidence (BEC)". In the case of both Model 1 and Model 2, the results exhibited that (BEX) had a significant impact on the (BEC). Statistically, the influence of BEX on the BEC was found to be significant at $p \leq 0.001$ (M1: $\gamma=0.786, \mathrm{t}=6.890$; M2: $\gamma=0.797, \mathrm{t}=6.955)$.

The second research hypothesis assumes that "emotional confidence (BEC) has a direct and positive influence on consumer brand satisfaction (BPQ)". The results exhibited that BEC had a significant impact on the BPQ. Statistically, the influence of BEC on the BPQ was found to be significant $\mathrm{p} \leq 0.001$ (M1: $\gamma=0.689, \mathrm{t}=9.947 ; \mathrm{M} 2: \gamma=0.647, \mathrm{t}=9.340)$.

The third research hypothesis assumes that "Consumer brand satisfaction (BPQ) has a direct and positive influence on consumer brand loyalty (BL)". The results exhibited that BPQ had a significant impact on the BL. Statistically, the influence of BPQ on the BL was found to be significant at $\mathrm{p} \leq 0.001$ $(\mathrm{M} 1: \gamma=0.630, \mathrm{t}=7.572, \mathrm{M} 2: \gamma=0.258, \mathrm{t}=3.216$ ).

However, the fourth research hypothesis intentionally included in Model 2 assumes that "emotional confidence (BPQ) has a direct and positive influence on consumer brand loyalty (BL)". The influence of $\mathrm{EC}$ on $\mathrm{BL}$ was found to be significant at $\mathrm{p} \leq 0.001$ $(\mathrm{M} 2: \gamma=0.496, \mathrm{t}=5.857)$. 


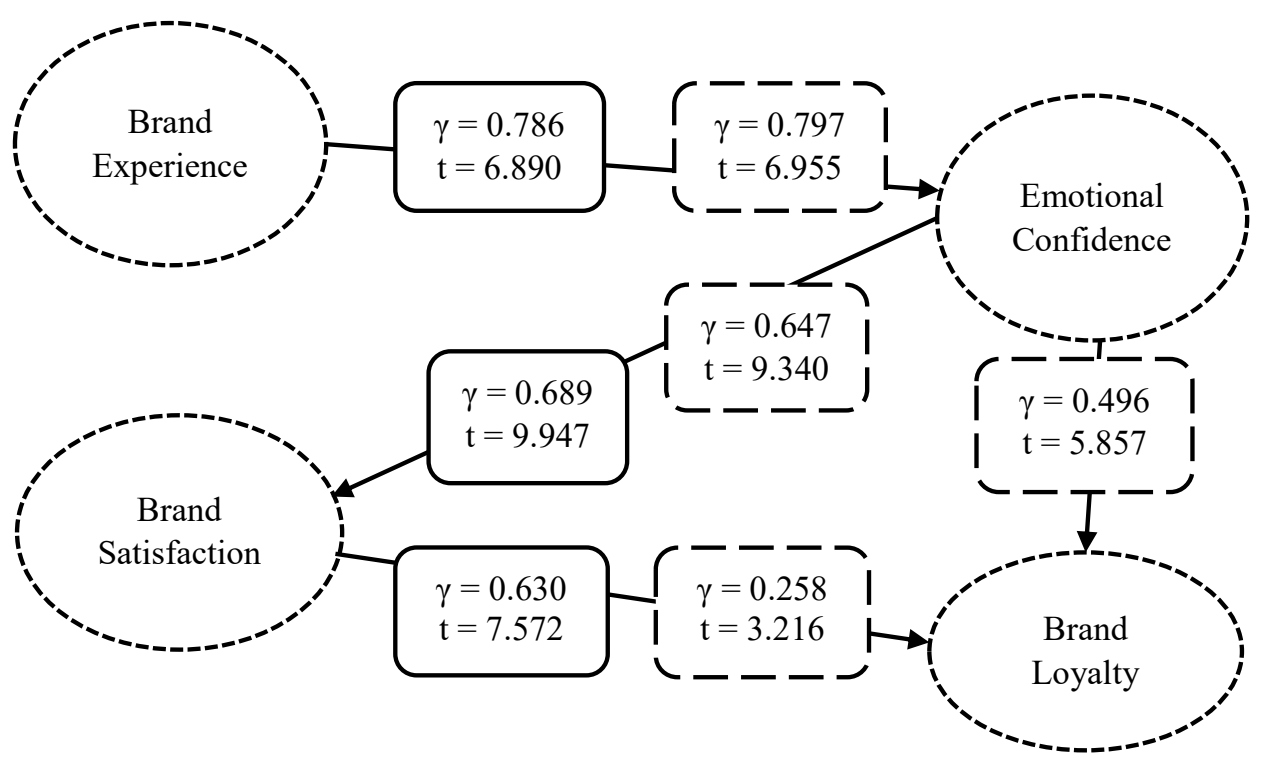

Figure 6. Path Estimates based on Model 1 (Straight Line) and Model 2 (Dotted Line) (Source: Own research)

\section{$5 \quad$ Cluster Analysis}

Table 10 shows the elicited clusters. Four clusters were extracted based on brand experience dimensions using hierarchical cluster analysis. Fig. 7 shows a graphical representation of the brand experience dimensions along the elicited clusters. Cluster 1 shows above-average scores on all the dimensions, whereas Cluster 2 shows below average on all the dimensions. Cluster 3 indicates the highest intellectual aspect with relatively lower, but above average sensory experience; in this cluster behavior, the experience is the lowest with relatively higher but below average emotional experience. Cluster 4 shows that behavioral, sensory and emotional experience is above average with below average intellectual experience. The primary objective of these clustering was to observe how the clustering of brand experience dimensions depicts the relationship among brand loyalty, brand satisfaction and emotional confidence.

Table 10. Elicited Clusters based on brand experience dimensions (Source: Own research)

\begin{tabular}{|c|c|c|c|c|c|}
\hline & $\mathrm{N}$ & Sensory & Affective & Behavioural & Intellectual \\
\hline 1 & 70 & 10.58 & 9.47 & 9.51 & 10.84 \\
\hline 2 & 97 & 8.57 & 6.65 & 5.98 & 7.19 \\
\hline 3 & 26 & 11.76 & 7.57 & 5.00 & 13.46 \\
\hline 4 & 47 & 11.36 & 10.40 & 11.12 & 7.87 \\
\hline Total & 240 & 10.05 & 8.31 & 7.91 & 9.07 \\
\hline
\end{tabular}

Fig. 8 shows scores of emotional confidence, brand loyalty and brand satisfaction. As expected, the above-average scores of all the brand experience dimensions depict higher brand loyalty, and emotional confidence and brand satisfaction are slightly below average. Similarly, that was the case in the second cluster blow average brand experience pulled the brand loyalty and emotional confidence and brand satisfaction downwards; however, correspondents of the brand satisfaction was less. Interestingly, in the third cluster, higher intellectual and sensory experience pulled the brand loyalty and emotional confidence upwards but that was not the case with brand satisfaction. 


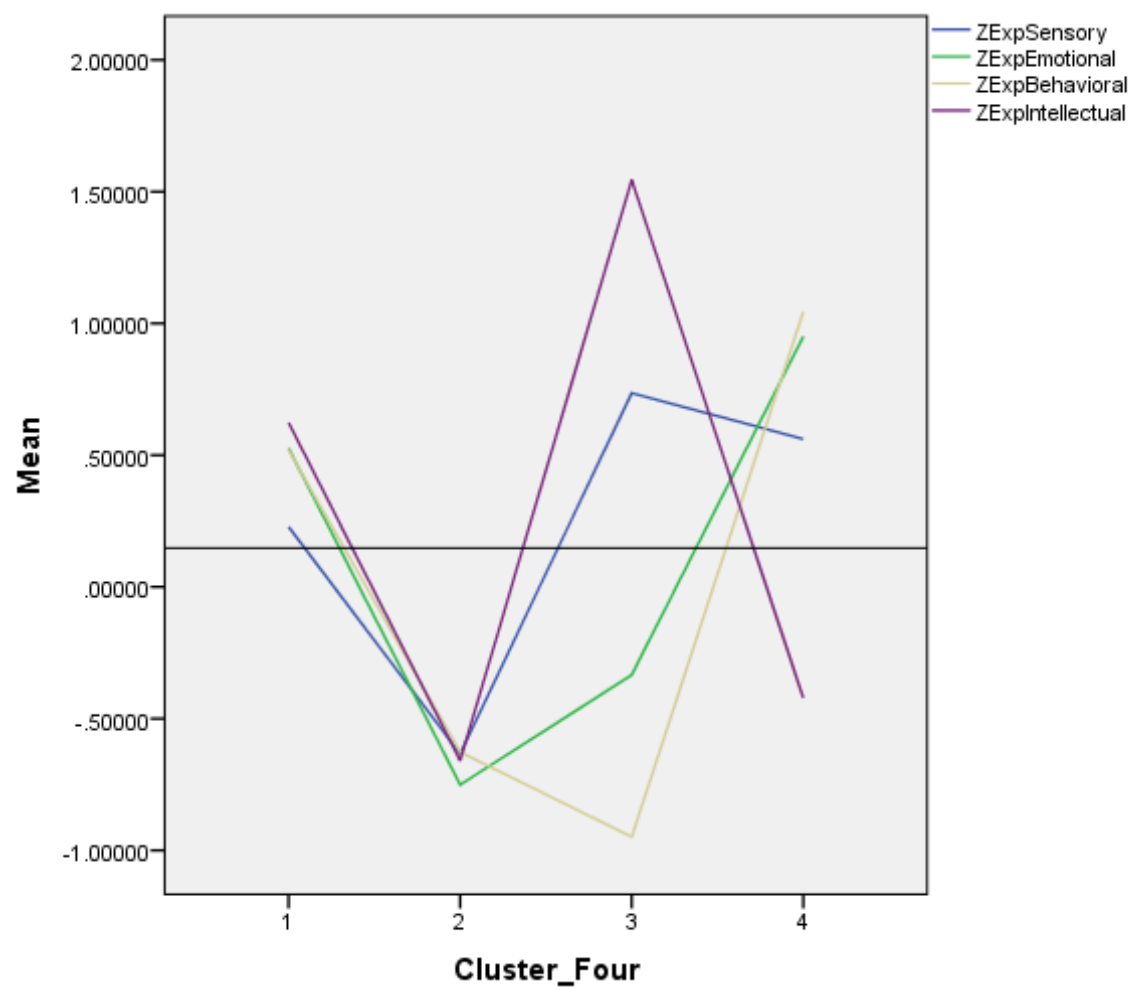

Figure 7. BE Dimensions Clusters (Source: Own research)

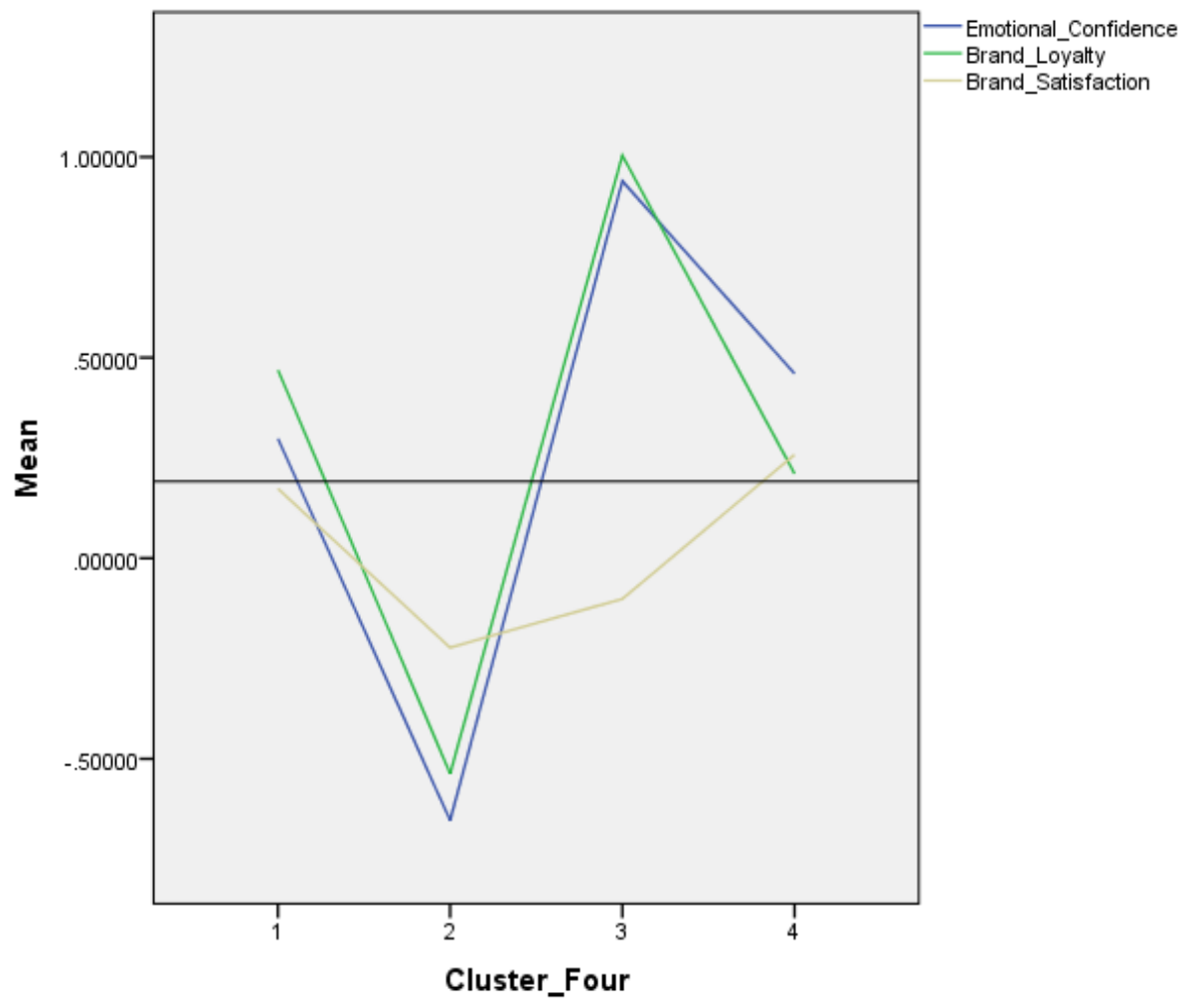

Figure 8. EC, BS and BL within BE Clusters (Source: Own research) 


\section{Conclusion and Discussion}

This study affirms that brand experience in the context of car buying influenced emotional confidence, and there was a positive and statistically significant influence of brand experience on emotional confidence. The results show that within the framework, emotional confidence plays an essential role as there is a positive and statistically significant influence on brand satisfaction. The inclusion of a direct path in the model increases the relative model fit (SEM) as the value of chi-square further reduced. The affirmation of the hypotheses paved the way for further analysis, the use of structural equation modeling just showed the holistic impact of brand experience on emotional confidence. The relatedness of the subdimensions (i.e., sensory, affective, intellectual and behavioral) was not fully explored. The relationship between emotional confidence, brand satisfaction, and brand loyalty was further analyzed through clustering of the brand experience sub-dimensions. Four clusters were elicited (see Fig. 7).

In Cluster 1, all BE dimensions were above average, whereas in Cluster 2 all BE dimensions were below average, both clusters were pretty distinct. However, Cluster 3 and Cluster 4 showed some exciting patterns and the main contrast was based on intellectual experience. In Cluster 3, intellectual experience was highest and sensory experience was above average, whereas behavioral experience was lowest and affective experience was below average. In Cluster 4, intellectual experience was most depressed and behavioral experience was highest, and both affective and sensory experiences were below average. The relationships between EC, BS and BL within the elicited clusters were observed (see Fig. 8).

The observation suggests that higher BE (Cluster 1) depicts higher EC, BS and BL. Similarly, lower BE (Cluster 2) suggests lower EC and BL; the BS satisfaction dipped down but not as much as the $\mathrm{EC}$ and BL. The observation of Cluster 3 was interesting as both $\mathrm{EC}$ and $\mathrm{BL}$ was the highest, and BS was below average. Contrary to the assumption that higher affective experience should translate into higher EC and BL. Similarly, in Cluster 4, when intellectual experience was below average, the EC and BL dipped; it seems like the intellectual experience drives the EC and $\mathrm{BL}$.

\section{$7 \quad$ Limitations and Future studies}

The use of judgmental sampling reduces the scope and generalizability of the study. Sample size $(n=240)$ for performing cluster analysis is not sufficient as more clusters can be observed with higher sample size. However, this study shows some interesting pattern that can further either be replicated or refuted with a higher sample size.

\section{$8 \quad$ References}

[1] Alam, S. and Yasin, N., 2010. The Antecedents of Online Brand Trust: Malaysian Evidence. Journal of Business Economics and Management, 11(2), pp.210-226.

[2] Alloza, A., 2008. Brand Engagement and Brand Experience At BBVA, The Transformation of a 150 Years Old Company. Corporate Reputation Review, 11(4), pp.371-381.

[3] Ambler, T., Bhattacharya, C.B., Edell, J., Keller, K.L., Lemon, K.N. and Mittal, V., 2002. Relating Brand and Customer Perspectives on Marketing Management. Journal of Service Research, 5(1), pp.13-25.

[4] Anderson, E. and Sullivan, M., 1993. The Antecedents and Consequences of Customer Satisfaction for Firms. Marketing Science, 12(2), pp.125143.

[5] Beatty, S. and Kahle, L., 1988. Alternative Hierarchies of the Attitude-Behavior Relationship: The Impact of Brand Commitment and Habit. Journal of the Academy of Marketing Science, 16(2), pp.1-10.

[6] Bennett, R. and Rundle-Thiele, S., 2004. Customer Satisfaction Should Not Be the Only Goal. Journal of Services Marketing, 18(7), pp.514523.

[7] Berman, B. and Telen, S., 2004. A Guide to Developing and Managing a Well-Integrated Multichannel Retail Strategy. International Journal of Retail and Distribution Management, 32(3), pp.147-156.

[8] Brakus, J., Schmitt, B. and Zarantonello, L., 2009. Brand Experience: what is it? How is it 
Measured? Does it Affect Loyalty? Journal of Marketing, 73(3), pp.52-68.

[9] Chaudhuri, A. and Holbrook, M., 2001. The Chain of Effects from Brand Trust and Brand Affect to Brand Performance: the Role of Brand Loyalty. Journal of Marketing, 65(2), pp.81-93.

[10] Dick, A. and Basu, K., 1994. Customer Loyalty: Toward an Integrated Conceptual Framework. Journal of the Academy of Marketing Science, 22(2), pp.99-113.

[11] Fetscherin, M. and Heillman, T., 2015. Consumer Brand Relationships: Meaning, Measuring, Managing. London: Palgrave Micmillan.

[12] Fredrickson, B., 2004. Gratitude, Like Other Positive Emotions, Broadens and Builds. In: R. Emmons and M. McCullough, eds. The Psychology of Gratitude. New York: Oxford University Press, pp.145-66.

[13] Grisaffe, D. and Nguyen, H., 2011. Antecedents of Emotional Attachment to Brands. Journal of Business Research, Volume 64, pp.1052-1059.

[14] Ha, H. and Perks, H., 2005. Effects of Consumer Perceptions of Brand Experience on the Web: Brand Familiarity, Satisfaction and Brand Trust. Journal of Consumer Behaviour, Volume 4, pp.438-452.

[15] Iglesias, O., Singh, J. and Batista-Foguet, J., 2011. The Role of Brand Experience and Affective Commitment in Determining Brand Loyalty. Brand Management, pp.570-582.

[16] Khan, I. and Rahman, Z., 2015. A Review and Future Directions of Brand Experience Research. International Strategic Management Review, 3(1), pp.1-14.

[17] Kim, B. and Sullivan, M., 1998. The Effect of Parent brand Experience on Line Extension Trial and Repeat Purchase. Marketing Letters, Vol. 9, pp.181-193.

[18] Kotler, P., Armstrong, G., Adam, S. and Denize, S., 2014. Principles of Marketing. Melbourne: Pearson Australia.

[19] Kotler, P. and Keller, K., 2009. Marketing Management. New Jersey: Prentice Hall.

[20] Kwang-Ho, A., Kim, M. and Hur, W.-M., 2011. Building Brand Loyalty Through Managing Brand Community Commitment. Management Decision, Vol. 49, No. 7, pp.1194-1213.
[21] Lacy, R., 2007. Relationship Drivers of Customer Commitment. Journal of Marketing Theory \& Practice, 15(4), pp.315-333.

[22] Lien, N.-H. and Kao, S.-L., 2008. The Effects of Service Quality Dimensions on Customer Satisfaction Across Different Service Types: Alternative Differentiation as a Moderator. In: Advances in Consumer Research. Association for Consumer Research (U.S.), Vol. 35, pp.522-526.

[23] Nam, J., Ekinci, Y. and Whyatt, G., 2011. Brand Equity, Brand Loyalty and Consumer Satisfaction. Annals of Tourism Research, 38(3), pp.1009-1030.

[24] Oliver, R., 1999. Whence Consumer Loyalty? Journal of Marketing, Volume 63, pp.33-44.

[25] Oliver, R., 2010. Satisfaction: A Behavioral Perspective on the Consumer. London: M.E. Sharpe.

[26] Ortmeyer, G. and Huber, J., 1991. Brand Experience as a Moderator of the Negative Impact of Promotions. Marketing Letters, Volume 2, pp.35-45.

[27] Park, C.W, MacInnis, D.J., Priester, J., Eisingerich, A.B. and Iacobucci, D., 2010. Brand Attachment and Brand Attitude Strength: Conceptual and Empirical Differentiation of Two Critical Brand Equity Drivers. Journal of Marketing, 74(6), pp.1-17.

[28] Pine, B. and Gilmore, J., 1999. The Experiential Economy: Work is Theatre and Every Business a Stage. Harvard Business School Press: Boston.

[29] Schmitt, B., 1999. Experiential Marketing: How to Get Customers to Sense, Feel, Think, Act, Relate to Your Company and Brands. New York: The Free Press.

[30] Schmitt, B., 1999. Experiential Marketing. Journal of Marketing Management, p.57.

[31] Shankar, V., Inman, J.J., Mantrala, M., Kelley, E. and Rizley, R., 2011. Innovations in Shopper Marketing: Current Insights and Future Research Issues. Journal of Retailing, Vol. 87S, pp.S29S42.

[32] Stajkovic, A., 2006. Development of a Core Confidence-higher Order Construct. Journal of Applied Psychology, 91(6), p.1208.

[33] Yoo, B. and Donthu, N., 2001. Developing and Validating a Multidimensional Consumer-based Brand Equity Scale. Journal of Business Research, 52(1), pp.1-14. 